Apidologie, 1981, 12 (3), 289-297.

\title{
STUDY ON SINEACAR EFFECTIVENESS IN CONTROLLING VARROA JACOBSONI*
}

\author{
Antonio Carlos STORT ${ }^{1}$ \\ Lionel Segui GONÇALVES ${ }^{2}$ \\ Osmar MALASPINA ${ }^{1}$ \\ Francisco A. MOURA DUARTE ${ }^{3}$
}

\begin{abstract}
SUMMARY
Sineacar is a powder made of a mixture of chlor and brom propylate, tedion and cellulose or glucose. 9 colonies were treated twice at 10 days intervals with 100 grams dusted over the combs. 5 colonies served as controls. The degree of infestation was determined before and several times after treatment.

The results showed no difference between treated and untreated colonies.
\end{abstract}

\section{INTRODUCTION}

The Varroa jacobsoni acarid is an ectoparasite attacking brood and adult bees of the genus Apis that is found in many parts of the world. According to MARIN (1978), this parasite is found in the apiaries of at least 28 countries. $V$. jacobsoni was first found and reported by OUDEMANS in 1904 on the island of Java, and today represents a serious threat causing considerable damage to apiaries in several continents.

The presence of Varroa jacobsoni in South America is quite recent, the acarid having first been reported by Dr. BogGino (MonTIEL, 1978) in Paraguay in 1973. However, the pest is presumed to have been introduced to Paraguay between 1971 and 1972 from Japan, where it existed since 1950. Several queen bees and brood affected by Varroa jacobsoni were brought to Brazil from Paraguay in 1972; however, the acarid was only first reported in 1978 (ALves et al.) in the State of São Paulo.

(*) Research carried out with the financial support of CNPq (Bilateral Agreement CNPg/NSF) and FAPESP.

' Departamento de Biologia, Instituto de Biociências de Rio Claro - UNESP.

${ }^{2}$ Departamento de Biologia, Faculdade de Filosofia, Ciências e Letras de Ribeirão Preto - USP.

${ }^{3}$ Departamento de Genética, Faculdade de Medicina de Ribeirão Preto - USP. 
In November, 1978, Morse and Gonçalves (1979) found severe infestation in apiaries located in Rio Claro, SP. This discovery motivated intensive inspection covering $80 \%$ of the State of São Paulo, which showed all inspected apiaries to be infested with $V$. jacobsoni (GonçALves et al., 1980). The acarid was also found in the States of Paraná, Minas Gerais, Rio de Janeiro, R. G. do Sul, E. Santo, Bahia and Piaui, and representing a serious threat to the Brazilian beekeeping industry, with $50 \%$ reduction in honey production already reported for the State of São Paulo.

The acarid was reported to be present in Argentina in 1976 (MONTIEL, 1978). According to Rubio (1979), Varroa has also been found in Uruguay, although the author does not mention the year when the pest wast first discovered in that country. One of the most drastic infestations reported in the literature occurred in Russia, where $V$. jacobsoni destroyed 55 thousand Apis mellifera colonies in 1971 (MONTIEL and Piola, 1976).

Several compounds such as Phenothiazine, Folbex, Horbex, Varostan, Varroazine, Dicofol and Sineacar have been used in the fight against the acarid in different countries, with variable and sometimes conflicting results. RITTER and RUTTNER (1980) have reported intensive chemotherapeutic studies for Varroa control which are being carried out in Germany since 1977. However, thus far no chemical compound has shown high efficiency. Varroa has also been causing serious problems in Japan, where it was introduced in 1950, and, according to SAKAI and TAKEUCHI (1980), $10 \%$ of beekeepers are still faced by this problem despite many attempts at control with different chemicals.

Application of Sineacar to fight varroatosis in Brazil was suggested to the Brazilian Apiculture Confederation at the XXVII World Apiculture Congress. Accordingly, the product was taken to Brazil from Rumania for testing. MARIN et al. (1978) have reported that Sineacar kills the acarids without damaging worker bees, brood, or queens. The objective of the present study was to test the efficacy of Sineacar in fighting varroatosis in africanized bees.

\section{MATERIAL AND METHODS}

The compound used, Sineacar, is a white-yellowish, not very strong-smelling powder acting on contact or by inhalation and having a specific effect on acarids (MARIN, 1979). The compound consists of a mixture of $1.5 \%$ chloride propilate and bromide propilate (Ciba Geigy) and $0.3 \%$ Tedion (Sandoz), with cellulose or glucose used as vehicles (RuTTER and RUTTNER, 1980).

Fourteen colonies of africanized bees Apis mellifera were used at the experimental apiary of the Bioscience Institute of Rio Claro (UNESP). Nine colonies (Nos. 8, 1T, 62, 6, 67, 2, 1, 5, and 4) were treated with Sineacar after the level of infestation had been determined, serving as a first control. The remaining five colonies (Nos. 1x, 71, 4H, 1Y, and 28) received no treatment and were used as controls.

The following method was used to determine the level of infestation by adult acarids for each colony : a frame was removed from the center of the brood nest and the workers swept with a brush into a beaker containing $150 \mathrm{ml}$ of $96 \%$ alcohol (Fig. 1) until the $200 \mathrm{ml}$ mark was reached, a volume corresponding to 


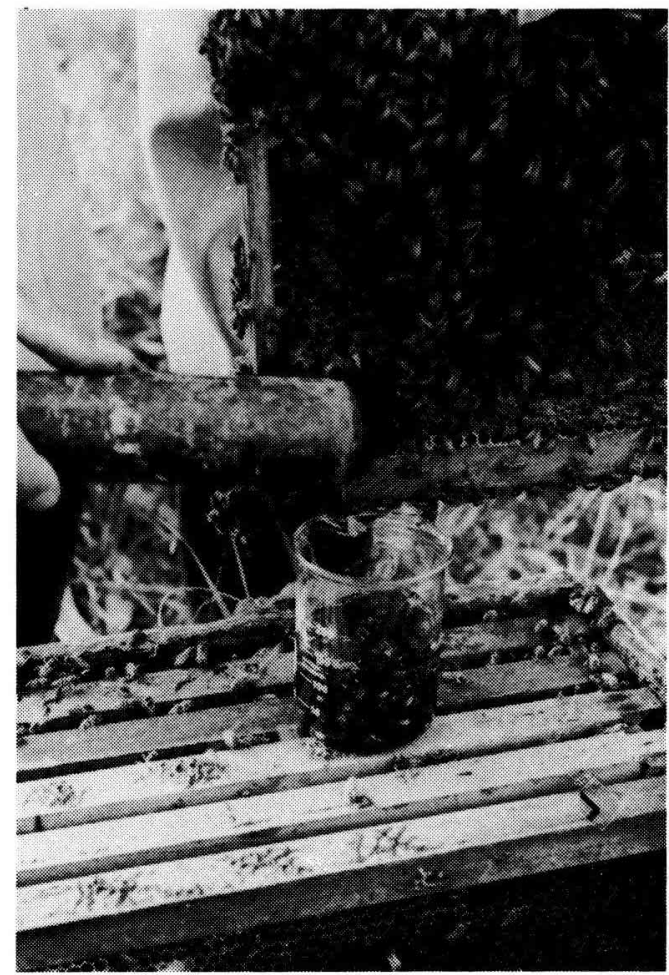

FIG. 1. - Beaker place on an open hive, containing $150 \mathrm{ml}$ of $96 \%$ alcohol and filled with bees until the alcohol reaches the $200 \mathrm{ml}$ level. This volume corresponds to about 300 to 500 bees per hive inspected for the presence of Varroa jacobsoni.

about $300-500$ bees. These samples were then placed in a plastic container fitted internally with a metal net used to separate the acarids falling off the bees (Fig. 2). The container was placed in a mechanical shaker for $\mathbf{3 0}$ minutes so that the acarids still attached to the bees could also be separated. All workers and acarids were counted for each sample, the number of acarids/number of bees $\times 100$ ratio was calculated and used as an index for the level of infestation in each colony. To determine whether the results of collections carried out at different times of day differed amongst themselves, a comparison was made among the data for 6 untreated colonies (Nos. 2, 5, 6, 8, 62, and 67) obtained from collections performed at 9:00 AM, 1:30 PM and 4:15 PM.

Sineacar was applied by dusting 100 grams of the powdered product on both sides of combs covered with bees. The remainder was applied between combs, on the bottoms, inner surface of the lids, and inside walls of the hive bodies. The entrance to the hive was smoked to force the bees to move around and thus spread the applied Sineacar thoroughly. Two applications were made. Samples for analysis of the effect of Sineacar were collected on the 10th day after the first application. The number of acarids obtained after each treatment was compared with those obtained before treatment of the same hives and with the five untreated hives. The first Sineacar application was made on December 29, 1979, and the colony samples 10 days later, just before applying the second treatment. Samples were also collected 10 , $27,51,65$, and 120 days after the second application. The data obtained, corresponding to percentage of infestation, were transformed into arc-sine for stabilization of variance, so that analysis of variance could be conducted. The data were considered to be an entirely randomized delineation. Analysis of variance was performed based on the linear model of OSTLE (1963): Yij $=u+\tau_{i}+\varepsilon i j$ with $u$ being the real mean 
Where :

$$
\begin{array}{lll}
i=1 & \ldots & t \\
j=1 & \ldots & n_{l} \text { (unequal numbers) }
\end{array}
$$

effect, $\tau_{t}$ the real effect of the $i t h$ statistical treatment, and $\varepsilon i j$ the real effect of the $j t h$ experimental unit subject to the $i t h$ statistical treatment. Seven statistical treatments $(t=1$ to 7$)$ and $n_{t}$ experimental units $(j=1$ to 9$)$ were utilized. The $t_{1}$ treatment was considered to be the main control of the experiment. The following comparisons were made :

$a$ - control (treatment 1) vs. the remainder,

$b$ - among the remainder,

$c$ - control vs. each treatment, separately.
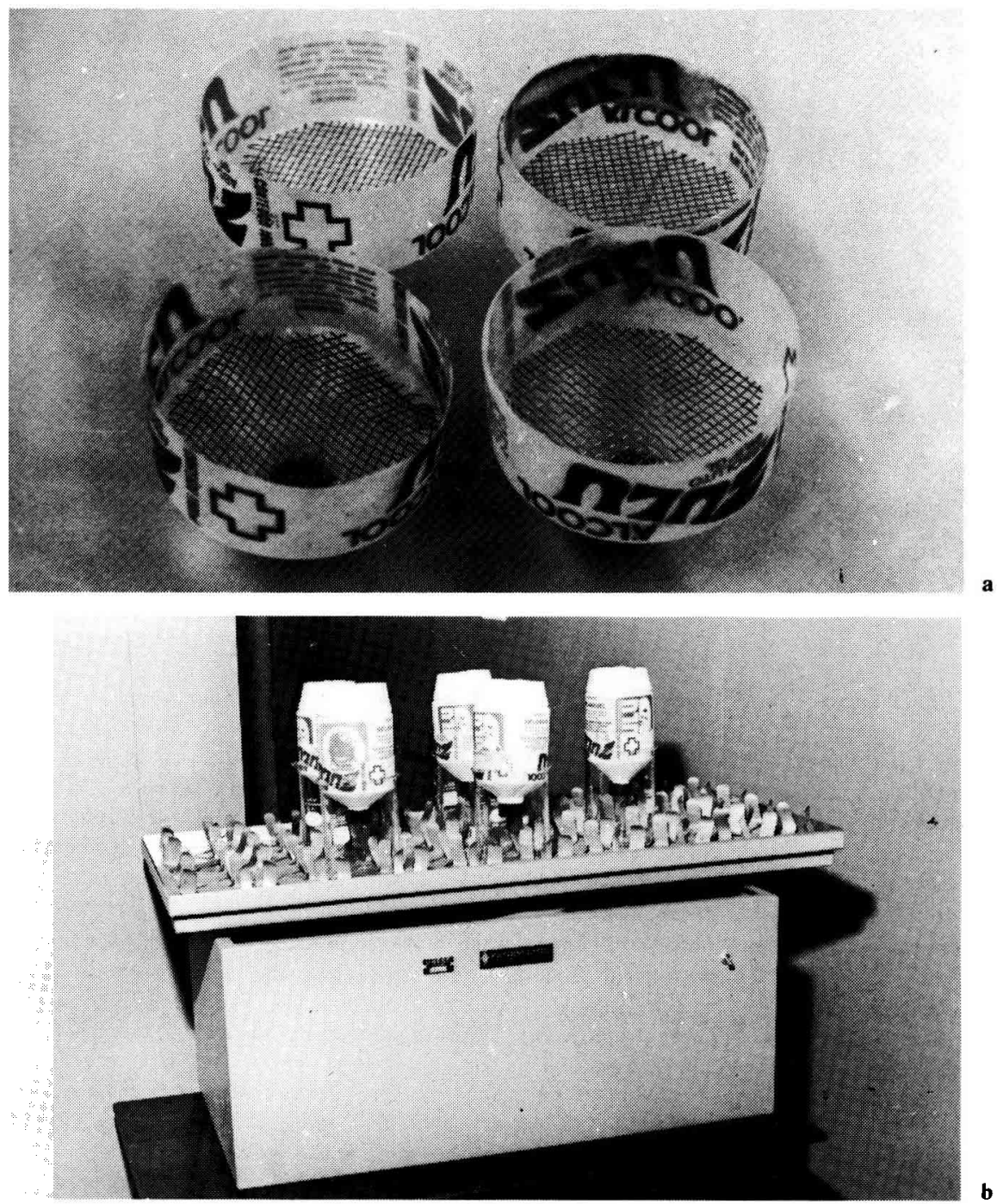

FIG. 2. - Plastic containers fitted internally with a wire net used to separate the acarids removed from the bees (a) after 30 minutes in a mechanical shaker (b). 
Nine colonies were taken as experimental units, and the percentage of acarid infestation was determined at random for each one. For better accuracy, the results obtained for the nine colonies were also compared with those for five other colonies, which were also controls not submitted to Sineacar treatment, using the same linear model for analysis of variance. Before comparing the data for control and Sineacar-treated colonies, the data for worker samples from six colonies infested with $V$. jacobsoni collected at the three different times of day were studied by analysis of variance.

\section{RESULTS AND DISCUSSION}

Table 1 shows the infestation data for the collections made at three different times of day for six colonies of africanized bees. The level of infestation varied between $3.76 \%-19.58 \%$, with only one colony (No. 6) showing mean infestation of more

TABL. 1. - Levels of infestation with Varroa jacobsoni (in mean \%) from hives of africanized bees collected at three different times of day and not treated with Sineacar.

\begin{tabular}{c|c|c|c}
\hline \hline \multirow{2}{*}{ Colonies } & \multicolumn{2}{|c}{ Level of infestation in \% at three different times of day } \\
\cline { 2 - 4 } & $9: 00 \mathrm{AM}$ & $1: 30 \mathrm{PM}$ & $4: 15 \mathrm{PM}$ \\
\hline 62 & 3.84 & 4.11 & 3.76 \\
67 & 5.59 & 4.14 & 3.76 \\
5 & 5.59 & 5.95 & 6.99 \\
2 & 11.97 & 13.42 & 7.69 \\
8 & 7.91 & 6.30 & 4.57 \\
6 & 17.44 & 19.58 & 13.81 \\
Mean & 8.72 & 8.90 & 6.74 \\
\hline
\end{tabular}

than $15 \%$. The means for each colony group ranged between $6.7 \%-8.9 \%$. However, analysis of variance gave nonsignificant results $(F=0.327386$, Table 2$)$, showing that these data do not differ amongst themselves and that the time of day has no influence on the level of infestation.

TABL. 2. - Analysis of variance related to comparison of data of $\mathrm{V}$. jacobsoni infestation in colonies of africanized bees whose sample were collected at three different times of day.

\begin{tabular}{lr|r|r|r}
\hline \hline \multicolumn{2}{c|}{ Source of variation D. F. } & S. S. & M. S. & F \\
\hline Total & 17 & 0.042363 & & \\
Treatment & 2 & 0.001772 & 0.000886 & 0.327386 \\
Error & 15 & 0.040591 & 0.002706 & \\
\hline \hline
\end{tabular}

Nonsignificant.

A general analysis of Table 3 shows great variability in infestation from the beginning to the end of the experiment both for the nine experimental colonies and the five untreated ones, with values ranging between $2 \%-27 \%$ in the treated colonies 
TABL. 3. - Results obtained for samples from nine experimental colonies of africanized bees collected before Sineacar treatment, 10 days after the first application, and 10,27,51,65, and 120 days after the 2nd application, and results for five untreated control colonies collected at the same times as the experimental sample.

\begin{tabular}{|c|c|c|c|c|c|c|c|}
\hline \multirow[b]{3}{*}{ Colonies } & \multirow{3}{*}{$\begin{array}{c}\text { Before } \\
\text { 1st application }\end{array}$} & \multicolumn{6}{|c|}{ Sineacar Application } \\
\hline & & \multirow[b]{2}{*}{$\begin{array}{c}10 \text { days after } \\
\text { 1st application (T2) }\end{array}$} & \multicolumn{5}{|c|}{ Days after 2nd application } \\
\hline & & & $\mathrm{T} 3=10$ & $\mathrm{~T} 4=27$ & $\mathrm{~T} 5=51$ & $\mathrm{~T} 6=65$ & $\mathrm{~T} 7=120$ \\
\hline $\begin{array}{r}8 \\
1 \mathrm{~T} \\
62 \\
6 \\
67 \\
2 \\
1 \\
5 \\
4 \\
\end{array}$ & $\begin{array}{r}8.60 \\
9.50 \\
3.50 \\
24.50 \\
4.10 \\
14.30 \\
10.20 \\
9.10 \\
8.80 \\
\end{array}$ & $\begin{array}{r}9.12 \\
1.67 \\
3.82 \\
17.79 \\
3.08 \\
7.20 \\
13.51 \\
9.59 \\
10.77 \\
\end{array}$ & $\begin{array}{r}11.60 \\
3.30 \\
3.46 \\
22.20 \\
3.43 \\
16.66 \\
19.48 \\
8.42 \\
27.24 \\
\end{array}$ & $\begin{array}{r}5.21 \\
2.73 \\
3.03 \\
12.99 \\
5.72 \\
9.53 \\
11.91 \\
8.02 \\
7.18 \\
\end{array}$ & $\begin{array}{r}4.92 \\
4.94 \\
5.79 \\
- \\
7.72 \\
12.44 \\
20.32 \\
7.14 \\
12.01 \\
\end{array}$ & $\begin{array}{r}1.96 \\
3.23 \\
6.20 \\
- \\
4.72 \\
4.45 \\
7.18 \\
7.08 \\
5.74 \\
\end{array}$ & $\begin{array}{r}4.48 \\
2.46 \\
4.28 \\
- \\
15.80 \\
3.58 \\
6.55 \\
2.63 \\
5.95\end{array}$ \\
\hline Mean & 10.29 & 8.51 & 12.87 & 7.37 & 9.41 & 5.00 & 5.71 \\
\hline $\begin{array}{r}\mathrm{X} \\
71 \\
4 \mathrm{H} \\
\mathrm{Y} \\
28\end{array}$ & $\begin{array}{l}- \\
- \\
- \\
- \\
-\end{array}$ & $\begin{array}{r}13.39 \\
6.56 \\
7.44 \\
3.67 \\
9.64 \\
\end{array}$ & $\begin{array}{r}10.93 \\
5.23 \\
6.78 \\
4.62 \\
6.32 \\
\end{array}$ & $\begin{array}{r}7.21 \\
8.17 \\
9.00 \\
5.63 \\
24.37 \\
\end{array}$ & $\begin{array}{r}18.27 \\
7.97 \\
3.44 \\
4.66 \\
10.25 \\
\end{array}$ & $\begin{array}{r}4.45 \\
20.78 \\
3.35 \\
4.18 \\
12.65 \\
\end{array}$ & $\begin{array}{l}6.65 \\
7.58 \\
3.67 \\
4.73 \\
9.13\end{array}$ \\
\hline Mean & - & 8.14 & 6.78 & 10.88 & 8.92 & 9.08 & 6.35 \\
\hline
\end{tabular}

The data in the table are number of acarids per bee expressed as mean/colony percentage. For analysis of variance, the percentage data were transformed into arc-sine.

and $3 \%-24 \%$ in the controls. When the data obtained for the experimental colonies were compared to those obtained after the 1 st and 2nd application, isolated cases showed wide fluctuations, with a few colonies exhibiting reduced numbers of acarids and others exhibiting increased numbers of acarids. When the means from $T_{1}$ (control) to $T_{7}$ were analyzed, a slight reduction in infestation from $10.29 \%$ to $8.51 \%$ was noted on the 10th day after the first application. However, 10 days after the second application the same hives showed increased incidence up to $12.87 \%$, with continued oscillations up to the 120th day after the 2nd application. The five untreated control colonies also showed great variation in infestation throughout the experiment, with varying means whose values were sometimes increased and sometimes reduced. When the means for the experimental colonies are compared with those for the untreated controls for each sample collection, the former are found to be sometimes higher and sometimes lower than the latter. For example, on the 10th day after the 2nd Sineacar application, the mean for the experimental colonies was $12.87 \%$, while that for the untreated control colonies was $6.78 \%$. Thus, the incidence was higher in the experimental colonies. On the 27 th day after the 2 nd application, the mean for the experimental colonies was $7.37 \%$, while the control had a mean of $10.88 \%$. This 
type of oscillation lasted until the end of the experiment (120th day), with no total acarid elimination occurring in the treated colonies. The results of the analysis of variance applied to the transformed percentage data (Table 4) were not statistically significant for any of the comparisons, showing no difference between treatment and controls. In contrast to MARIN's recommendation (1977), these results indicate a lack of Sineacar in controlling $V$. jacobsoni.

Different pesticides have been used in several countries where varroatosis represents a serious problem for apiculture. Application of Sineacar in West Germany gave no satisfactory results (RITTER, 1979, RITTER and RUTTNER, 1980; KOENINGER, RITTER and RUTTNER, 1980), as confirmed by our results. Therefore we conclude that Sineacar did not produce the hoped for effect, proving to be ineffective in the control of V. jacobsoni.

TABL. 4. - Analysis of variance and treatment comparison of infestation data for the nine colonies of africanized bees shown in Tabl. 3.

\begin{tabular}{l|c|c|c|c}
\hline \multicolumn{1}{c|}{ Source of Variation } & D. F. & S. Squares & Mean S. & $F^{*}$ \\
\hline Mean & 1 & 0.440322 & 0.440322 & - \\
Treatments & 6 & 0.038626 & 0.006438 & 2.06 \\
Controls (T1) $\times$ remainder & 1 & 0.003292 & 0.003292 & 1.06 \\
Among the remainder & 5 & 0.035333 & 0.007067 & 0.96 \\
Control $\times$ T2 & 1 & 0.001463 & 0.001463 & 0.49 \\
Control × T3 & 1 & 0.003093 & 0.003093 & 0.99 \\
Control × T4 & 1 & 0.003916 & 0.003916 & 1.26 \\
Control × T5 & 1 & 0.000337 & 0.000337 & 0.11 \\
Control × T6 & 1 & 0.012042 & 0.012042 & 3.87 \\
Control × T7 & 1 & 0.008977 & 0.008977 & 2.89 \\
Experimental Error & 53 & 0.165700 & 0.003126 & - \\
\hline Total & 60 & 0.644648 & - & - \\
\hline
\end{tabular}

* All F values were nonsignificant.

Received for publication in April 1981 .

\section{RÉSUMÉ}

\section{ÉTUDE DE L'EFFICACITÉ DU SINÉACAR DANS LA LUTTE CONTRE VARROA JACOBSONI}

Le but de cette recherche est de tester l'efficacité de l'acaricide Sinéacar vis-à-vis de l'acarien Varroa jacobsoni, ectoparasite du genre Apis, qui est répandu sur la majeure partie du globe et qui cause des dommages considérables à l'apiculture dans de nombreux pays, y compris le Brésil. Le Sinéacar est une poudre jaune blanchâtre, de faible odeur, constituée d'un mélange de propylate de chlore et de brome, de tédion et de cellulose ou de glucose. Ce poison agit par contact et inhalation.

Pour ce test on a utilisé 14 colonies d'abeilles africanisées, 9 traitées et 5 témoins. Avant d'administrer le Sinéacar on a déterminé le degré d'infestation de chaque colonie en brossant 300 à 500 ouvrières dans un 
bécher rempli d'alcool éthylique à $96 \%$ et en plaçant le mélange sur un agitateur pendant 30 minutes afin de séparer les acariens des abeilles. Ceci a fourni un chiffre pré-traitement correspondant au nombre moyen d'acariens par 100 abeilles. Le traitement a consisté à saupoudrer $100 \mathrm{~g}$ de Sinéacar dans chaque colonie sur les rayons, le plancher, les parois et la face interne du toit. On a fait 2 applications à 10 jours d'intervalle. Des abeilles ont de nouveau été prélevées pour déterminer le degré d'infestation 10, 27, 51, 65 et 120 jours après le $2^{e}$ traitement. Pour l'analyse statistique on a fait subir aux données une transformation arcsinus afin de réaliser une analyse de la variance. Les résultats ne montrent aucune différence entre les colonies traitées et les colonies témoins, ce qui prouve que l'acaricide Sinéacar est inefficace contre l'acarien Varroa jacobsoni.

\section{ZUSAMMENFASSUNG}

\section{UNTERSUCHUNG ÜBER DIE WIRKSAMKEIT VON SINEACAR BEI DER KONTROLLE VON VARROA JACOBSONI}

Ziel dieser Untersuchung war die Prüfung der Wirksamkeit des Akarizids Sineacar auf die Milbe Varroa jacobsoni, einem Ektoparasiten der Biene, der über einen Grossteil der Welt verbreitet ist und der die Bienenzucht in vielen Ländern einschliesslich Brasiliens beträchtlich schädigt. Sineacar ist ein weissgelbliches Pulver mit schwachem Geruch, bestehend aus einer Mischung von Chlor- und Brompropylat, Tedion und Zellulose oder Glukose. Es ist ein Kontakt- und Atemgift.

Für diesen Versuch wurden 14 Völker von afrikanisierten Bienen verwendet, 9 Versuchsvölker und 5 Kontrollen. Vor der Anwendung von Sineacar wurde der Befallsgrad an jedem Volk dadurch bestimmt, dass 300-500 Arbeitsbienen in einen Becher mit $96 \%$ Äthylalkohol gekehrt und dann für 30 Minuten in einem Schüttelgerät bewegt wurden, um die Milben von den Bienen zu trennen. Das gab einen Anhaltspunkt für die mittlere Milbenzahl pro 100 Bienen. Die Behandlung bestand darin, dass $100 \mathrm{~g}$ des SineacarPulvers in jedes Volk gestäubt wurden, auf die Waben, auf das Bodenbrett, die Beutenwände und auf die Innenseite des Deckels. Es wurden zwei Behandlungen mit einem Intervall von 10 Tagen durchgeführt. 10, 27, 51, 65 und 120 Tage nach der zweiten Anwendung wurden zur Bestimmung des Befallsgrades Bienen untersucht. Für die statistische Analyse wurden die Daten für die Durchführung einer Varianzanalyse einer Arc-Sinus-Transformation unterzogen. Dic Resultate zeigten keinen Unterschied zwischen den Behandlungen und den Kontrollen und zeigten somit, dass das Akarizid Sineacar zur Behandlung der Milbe Varroa jacobsoni wirkungslos ist.

\section{BIBLIOGRAPHY}

Alves S. B., Flechtman C. H. W. and Rosa A. E., 1978. - Varroa jacobsoni Oudemans, 1904 (Acari, Mesostigmata, Varroidae) also in Brazil. Ecossistema, 3 (3) : 78-79.

Gonçalves L. S., Soares A. E. E., Stort A. C., Buriolla A. H., Issa M. R. C., Steiner J. e Veloci M. E. P., 1980. - Estudo sobre o ácaro parasita de abelhas, Varroa jacobsoni. I. Grau de Infestação em apiários do Estado de São Paulo (Nota Preliminar). Resumos do $5^{\circ}$ Congresso Brasileiro de Apicultura e III Congresso Latino-Ibero-Americano de Apicultura, 23-27/7/1980, Viçosa-MG. pg. 91.

Koeniger N., RitTER W. and RUTTNER F., 1980. - Varroa jacobsoni and its control in the FRG. Abstracts of the XVI International Congress of Entomology. Kyoto - Japan, 3-9 August 1980, pg. 425.

MARIN M., 1977. - Diagnosis and treatment of varroasis. In : Varroasis, a Honeybee Disease, Apimondia Publishing House, Bucharest, pg. 17-19.

MARIN M., 1978. - World spread of varroa disease. Apiacta. 13 : 163-166.

MARIN M., 1979. - Prévention et lutte contre la varroase. In : Prophylaxie et lutte contre la varroase. Editions Apimondia. Bucarest, 1979. pp. 83-89.

Marin M., Velescu G. H., Ionescu D., Resu J., Ograda I., Anastasiu D. and Gilca C., 1978. - Varroa disease, diagnosis method and treatment. Proceedings of the XXVI International Apicultural Congress, Adelaide, Australia, p. 474. 
Montiel J. O., 1978. - Varroasis en abejas. Direccion Nacional de Fiscalizacion y Comercializacion Ganadera. Area de Granja. Ministerio de Ecomomia. Secretaria de Estado de Agricultura y Ganaderia.

Montiel J. O., Piola G. A., 1976. - A new enemy of bees. Campo moderno y chacra, October, 1976 : 36-37.

MorSE R. A. and GonçAlves L. S., 1979. - Varroa disease, a threat to world beekeeping. Gleanings in Bee Culture, 107 : 179-181, 202.

Ostle B., 1963. - Statistics in Research. Iowa State Univ. Press., 629 p.

RITTER W., 1979. - Le stade actuel de la lutte contre la varroase dans la région de Taunus; résultats des traitements appliqués pendant l'automne de l'année 1977. In : Prophylaxie et lutte contre la varroase. Editions Apimondia, Bucarest, pg : 78-82.

RitTER W. and RUTTNer F., 1980. - Chemoterapie Allgemeine Deutsche Imkerzeitung. Mai 1980: 138146.

Rubio Eduardo M., 1979. - Rocha - Uruguay. Una Gran Reserva Agricola Continental. Fundamentos para su indispensable creación expuestos por el director del plan de desarrollo apicola rochense. Gaceta del Colmenar Nov. 1979, 558-564.

SAKAI T. and TAKeUCHI K., 1980. - Varroa jacobsoni and its control in Japan. Abstracts of the XVI' International Congress of Entomology, Kyoto-Japan, 3-9 August 1980, pg. 425. 